\title{
An Environmental Philosophy for Music Education Based on Satis Coleman's (1878-1961) Writings on Music and Nature
}

\author{
Daniel J. Shevock \\ Penn State Altoona, USA
}

The 21st century has been defined by ecological crises, and these crises have been absent from most critical conversations in music teaching and learning. Satis Coleman's music education writings, influential in the 1920 s and 30s, focused on music and nature. The intellectual history presented in this essay, a historiography of ideas and thinkers, frames selected writings by Coleman as an environmental philosophy. This essay is built qualitatively around the themes of nature, consumption and conservation, epistemology/ethics/policy, and evolution. Coleman's environmental philosophy provides an opening for music educators to begin teaching and learning for eco-literacy through music.

Keywords: music education history, intellectual history, environmental ethics, environmental justice, eco-literacy, ecofeminism, nature

\footnotetext{
7 he 21st century has been defined by ecological crises. The UNESCO Earth Charter, conceived and written between 1987 and 2000, begins:

We stand at a critical moment in Earth's history, a time when humanity must choose its future.... Towards this end, it is imperative that we, the peoples of Earth, declare our responsibility to one another, to the greater community of life, and to future generations. ${ }^{1}$
}

As peoples of Earth, an increasing number of music educators have called for the field of music education to recognize its distinctive responsibilities in this regard (Bates 2013, Jorgensen 1997, Koza 2006, Lafontant Di Niscia 2017, Shevock and Bates 2019, Shevock 2018), responsibilities that have recently been institutionalized in the MayDay Group's Action Ideal IX. ${ }^{2}$ In this essay, I consider how the work of Satis Coleman (1878-1961) can inform an environmental philosophy for music education.

(C) Daniel J. Shevock. 2020. The content of this article is the sole responsibility of the author. The ACT Journal and the Mayday Group are not liable for any legal actions that may arise involving the article's content, including, but not limited to, copyright infringement. 
Coleman, in the first half of the 2oth Century, was a well-known and influential music educator whose ideas were largely ignored during the second half of the 20th century, the era of Music Education as Aesthetic Education. ${ }^{3}$ Coleman has been rediscovered, however, especially since the 1990s (Boston 1992; Shevock 2015; Southcott 1990, 2009; Volk 1996), coinciding with the increase in praxial ideas in music education-the "Praxial Turn"-representing a turn away from $\mathrm{Mu}$ sic Education as Aesthetic Education (Goble 2010, 238). In her induction into the NAfME Hall of Fame in 2010, Coleman was recognized as having "promoted music education for its ability to lead children to relate music to other subjects, such as history, geography, and the study of natural resources" (NAfME News 2010). Coleman recommended that "music teachers teach a deep understanding for the music of nature" (Shevock 2015, 59). Environmental philosophy may be understood, then, as one part of her overall music education philosophy, which overlapped with spiritual, scientific, and pedagogical concerns.

To clarify environmental aspects of Coleman's music education philosophy, I read environmental and scientific ideas of the early 2oth Century, when the bulk of Coleman's work was written. Current environmental philosophy, progressive education, the move toward Music Education as Aesthetic Education, and, more recently, the Praxial Turn, provide additional context. Her philosophy included important aspects of nature and society and was of consequence for music educators' roles in consumption. She discussed epistemological, ethical, and policy issues in an integrated manner; she was, however, influenced by Darwinian evolutionary thinking in social theory. In this essay, I situate Coleman's music education philosophy in a context of how teachers might increase students' eco-literacy through music education.

What I offer here, then, is an intellectual history. Intellectual history (and the closely related discipline, history of philosophy) can contextualize ideas such as Coleman's, clarifying the thoughts and ideas of other thinkers at the time, and may inform current practice by recognizing how previous eras' philosophies connect to current understandings. Intellectual history may be defined simply as the historiography of ideas and thinkers. Historian Richard Whatmore (2016) observed, "The intellectual historian has to start with the words" (Loc. 200). "Ideas are social forces. They may be shaped by other forces but they themselves, in turn, always influence the human world" (Loc. 332). Whatmore argued that philosophies are

Daniel J. Shevock. 2020. An environmental philosophy for music education based on Satis Coleman's (1878-1961) writings on music and nature. Action, Criticism, and Theory for Music Education 19 (1): 174-207. https://doi.org/10.22176/act19.1.174 
not always explicit or systematic. Rather, everyday knowledge, in history, provides an opportunity for analysis of ideas as a philosophy.

\section{Satis Coleman}

Coleman first taught music at a rural school in Texas, next in Washington, D.C., and then in New York City at the Lincoln Lab School from 1920-1942 and Teachers College, Columbia University (she taught summer sessions for Teachers College 1925-1942), where she earned undergraduate, masters, and doctoral degrees (Boston 1992, 34, 88).4 Over the course of her career, several major publishers (14752 ) issued her pedagogical, historical, and cultural texts, including two texts that I consider philosophical. Coleman was considered a model progressive music educator who placed rhythmic elements, "developed through bodily action" (Tellstrom 1971, 177), before melodic and harmonic elements. She was perhaps best known for incorporating simple instrument construction, which included the making of drums before wind and string instruments. "The Greek ideal of simplicity seemed to offer a possible answer ... to see if there could be found varying degrees of simplicity to suit the varying levels of children's natural musical capacity" (Coleman 1931, 12). Within instrument families, she seemed to have viewed some cultures' instruments as more advanced than others (see Image 1). This has been understood as an expression of Recapitulation Theory (Southcott 2009, see also Lesko 1996), which supported racist views, and which I unpack in this paper in the sections Epistemology/ethics/policy and Evolution.

Daniel J. Shevock. 2020. An environmental philosophy for music education based on Satis Coleman's (1878-1961) writings on music and nature. Action, Criticism, and Theory for Music Education 19 (1): 174-207. https://doi.org/10.22176/act19.1.174 


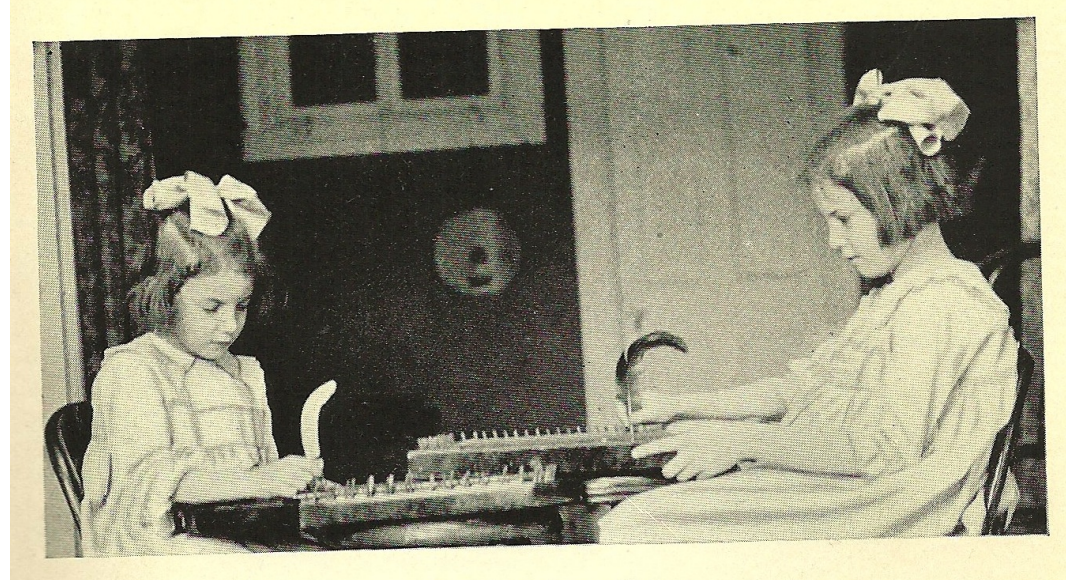

27. A Psaltery Duet

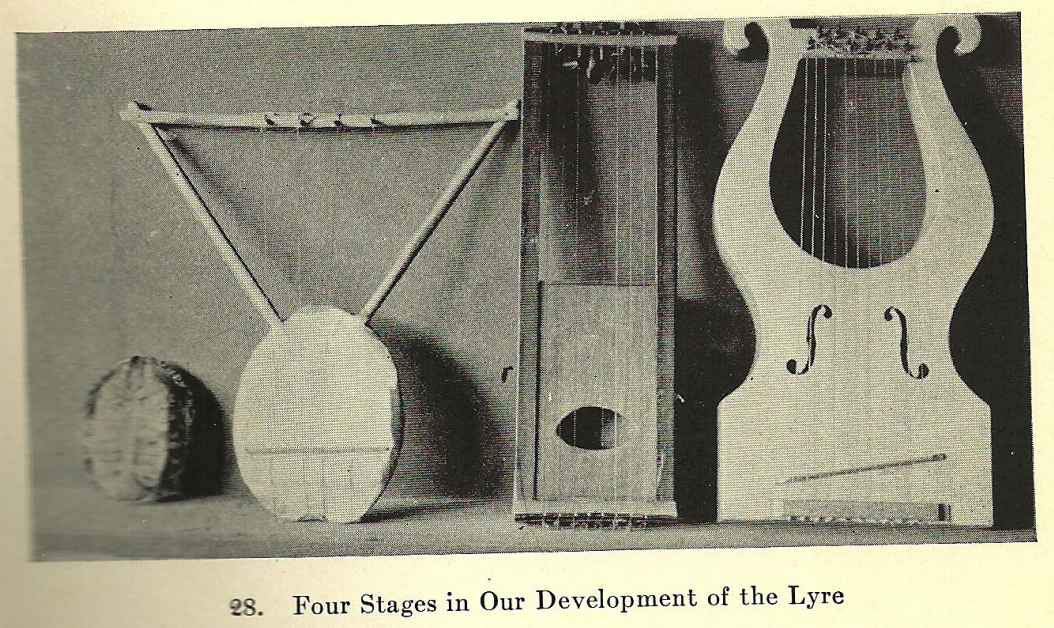

Image 1: Four Stages in Our Development of the Lyre (Coleman 1922, 142 insert)

Music-conceived as singing, dancing, instrument making and playing, and composing-represented means for Coleman's music education philosophy. Coleman's aims were interdisciplinary, called correlation in the early 2oth century. "The making and the manipulation of simple instruments tend to arouse interest in the physics of sound and in other scientific matters" (Coleman 1931, 21). In correlation theory, music educators taught students to recognize the correlations between music and other school subjects, such as mathematics, sciences, and geography:

Satis Coleman referred to correlation in regard to the construction of primitive instruments such as pipes and drums in the music class. She contended that such

Daniel J. Shevock. 2020. An environmental philosophy for music education based on Satis Coleman's (1878-1961) writings on music and nature. Action, Criticism, and Theory for Music Education 19 (1): 174-207. https://doi.org/10.22176/act19.1.174 
an activity carried the child beyond the mere practice of instrument-making and led him into the physics of sound as well as the manual arts. It further directed the children toward the history of many different peoples, their methods of making musical instruments, and also toward world geography and a knowledge of natural resources. Such training contributed toward a broader education. (Tellstrom 1971, 180)

This is what today we call interdisciplinarity. Since ecology is about relationships, correlation-the integration of various school subjects-seems like a natural ally to ecology, which analyzes the interconnections of beings in an ecosystem. 5

\section{Philosophy}

Coleman understood her work as a philosophy ${ }^{6}$ of music education, rather than as a method or system:

The type of work here described is not a "method" or "system." It is rather a point of view, an attitude, a philosophy, if you please, of music education which attaches great importance to the teaching of music to children, but is much more concerned with the growth of children. It stands for experiences that not only develop the child's musical sense, but also stimulate adventure and discovery in all fields related to music; that make use of the constructive tendencies of children to enhance their interest, knowledge and skill; that lead to free and original self-expression with both hands and mind, offering all children-whether talented or not-the opportunity to share in joyous creative experiences that lead to habits of creative work. (Coleman 1927a, 23, emphasis added)

She seemed to recognize the import of using the phrase, philosophy of music education, by inserting the clause if you please. Few, if any, music education writers at the time put forth an explicit philosophy of music education, and Coleman may be unique in this regard. Music education philosophers often begin by defining music, and Coleman similarly felt defining music in relation to education was important.

In considering the music education of young children I like to think of the word "music" in its old and original sense. You will recall that it is a Greek term (mous$i k e$ ) meaning the activities of the Muses; and this included all the Greek arts that involved sound or motion, with nothing static as an outcome. Dancing, song, pantomime, rhythmic language-even in tragedy and in the reciting of history-instrumental sounds, everything temporal and rhythmic was "music." All these things are by nature so closely bound together by the rhythmic element that it is difficult to isolate one from the other, and a pity to attempt it in the early music experiences of children. (Coleman 1925, 205)

Daniel J. Shevock. 2020. An environmental philosophy for music education based on Satis Coleman's (1878-1961) writings on music and nature. Action, Criticism, and Theory for Music Education 19 (1): 174-207. https://doi.org/10.22176/act19.1.174 
From the perspective of intellectual history, her scholarship may be considered philosophy even if it does not meet specific criteria for contemporary philosophical discourse (Whatmore 2016). Rather than systematic argument, she used storytelling to support her ideas and critiques. Storytelling, as Coleman utilized it, is similar to Plato's dialogues-artistic representations of ideas-especially the early Socratic dialogues that end in aporia, rather than making positive claims.7

In Coleman's (1927a) philosophy, the purpose of education was to enhance student "happiness" 8 (18) by fulfilling the "natural desire to make things" (22). Learning was accomplished by doing, not just by listening (23), which included singing, dancing, and making and improvising on homemade instruments. Coleman earned her Ph.D. in Educational Psychology in 1931 (Southcott 2009) in Columbia University's Department of Philosophy, and her dissertation (1931) referenced philosophers such as Plato and Aristotle, anthropologists including Franz Boas, and music historians. She did not, however, reference psychologists in her dissertation, nor did she reference John Dewey, although her writings aligned well with Dewey's philosophy (Southcott 2009, 23). In a later work, Coleman (1939) referred to Dewey's idea of interest:

They may force him to sit at the piano and go through the motions of practice, but they cannot force him to learn anything.... John Dewey, in his book Interest and Effort in Education, many years ago discussed this principle of learning. (1516)

She thought a general and "natural" music education was appropriate for everybody and that students should be free to follow their interests, even when that meant they left music study to follow other interests. Important to this essay, Coleman's writings can be read to provide an environmental philosophy-ideas that are rather atypical within music education.

\section{Environmental Philosophy}

Environmental philosophy clarifies how concepts related to the natural environment and society-including issues of consumption, conservation, epistemology, ethics, and policy-are defined (Sarkar 2012). For instance, "environmental ethics attempts to enlarge the domain of traditional (that is, human) ethics by extending our moral concern to non-human entities, to individual animals and plants, to

Daniel J. Shevock. 2020. An environmental philosophy for music education based on Satis Coleman's (1878-1961) writings on music and nature. Action, Criticism, and Theory for Music Education 19 (1): 174-207. https://doi.org/10.22176/act19.1.174 
entire non-human species, and sometimes even to inanimate objects" (4). Many movements, such as Deep Ecology and Ecofeminism (e.g., Shiva 1992), view this enlargement as essential in the 21st century. Coleman's music education focused on both human and non-human musics.

In contrast, Music Education as Aesthetic Education focused music educators' attention on the uniquely human aspects of music. For instance, Reimer (1989) considered learning about nature a mere topical approach to music education, one "without merit" (235). Though music and nature include aesthetic aspects, it is in the practices of human culture/social structures, and perhaps non-human/animal social structures as described by sociobiologists (see Fitch 2005, Rothenberg 2008) that Coleman's philosophy speaks to music education. Coleman's environmental writings, in other words, open space to think about environmental issues through music education.

\section{Nature}

Coleman understood the idea of nature in two main ways-Nature as Mother Earth, and nature as a pedagogical inspiration. She also used the word nature in other common ways. For instance, nature meant "customary," as when she wrote, "Natural peoples are impelled to express their deepest feelings in song" (Coleman 1942, 7). This conception of nature seemed to have been used both as a criticism of modern living and as a colonial way to define the other (addressed later in the paper, especially the discussion of evolution). "Nature" represents classification, e.g., "collections of a similar nature" (7); however, her use of Nature as a spiritual force, and nature as pedagogical, deserve closer attention.

\section{Mother Earth}

Coleman understood Nature (capitalized) as a spiritual force-Mother Earth. Linked with her conception of cultures as evolving, and in line with fellow Darwinian thinkers (Williams 1972), Coleman evoked Nature as a goddess. In The Book of Bells, she discussed the magic of bells.

The idea of the magic of bells probably started among primitive peoples long ago. In the early stages of the human race, when Primitive Man [sic] first found that he could produce a ringing sound in a stone, it must have seemed to him the voice

Daniel J. Shevock. 2020. An environmental philosophy for music education based on Satis Coleman's (1878-1961) writings on music and nature. Action, Criticism, and Theory for Music Education 19 (1): 174-207. https://doi.org/10.22176/act19.1.174 
of his god speaking the mysterious language of Mother Earth. For was not a stone a part of the sacred Underworld? And later, when men began to use iron, which gives a sound that is even louder and more ringing than stones, it seems natural that they should have thought of their bells as having magic power. (Coleman 1938, 20)

It is difficult to determine whether or not Coleman viewed this "primitive" understanding of music as magical as inferior to modern, rational approaches to thinking (in the same way Marxian thinkers code magical thinking negatively), but that may be read as implied. Anyone reading Coleman today would probably recognize the racist/colonialist trappings of the conceptualization of any group of people as "primitive." After recognizing this limitation, however, there are other things to gain from her writings. Coleman expressed distaste toward modern soundscapes, "the sound of paved streets, whirring machinery, trains, street-cars, automobile horns, radios" (Coleman 1939, 91); she recommended children learn to listen to "sweet silence" found in "the rhythmic beat of Nature, and have a bit of understanding of the voice of God" to develop both "musical powers" and "a healthy well-poised body" (92) (see Image 2).

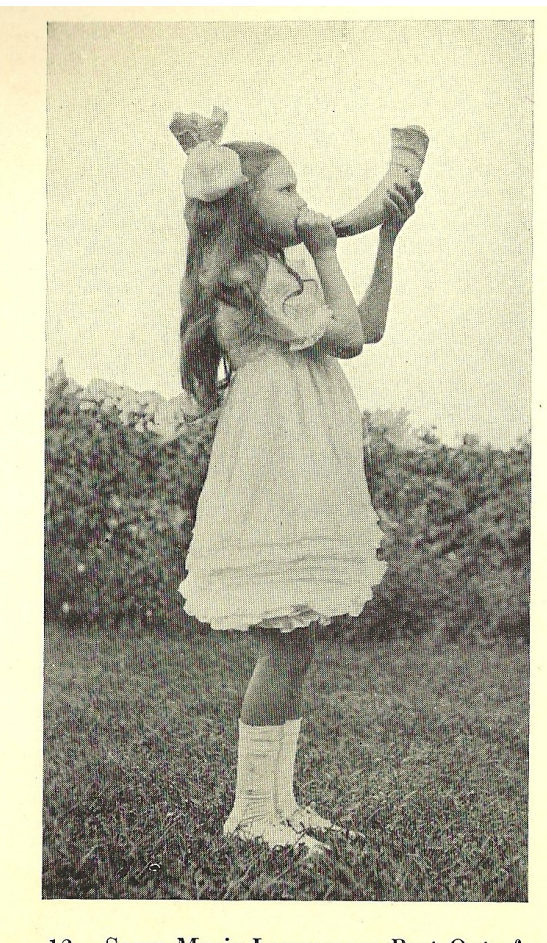

12. Some Music Lessons are Best Out of
Doors

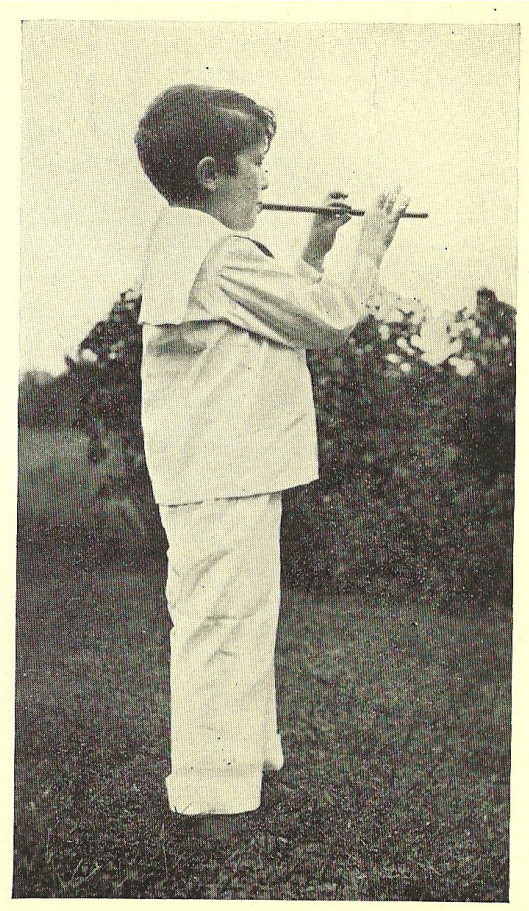

13. The Shepherd's Pipe

Image 2: Some Music Lessons are Best Out of Doors (Coleman 1922, 86 insert)

Daniel J. Shevock. 2020. An environmental philosophy for music education based on Satis Coleman's (1878-1961) writings on music and nature. Action, Criticism, and Theory for Music Education 19 (1): 174-207. https://doi.org/10.22176/act19.1.174 
Pedagogically, this understanding (and perhaps an anthropomorphic conception) of Nature was aimed at cultivating a "love" (Coleman 1939, 95) for Nature with all of the students' senses, including ears. Pedagogically, loving Nature in this way is in line with the Gaia Hypothesis, which aims to understand the biosphere organically, opening up interconnections between various scientific disciplines at work together in a large ecological system (e.g., Jorgensen 1997). It also provides an opening for a spiritual praxis (Shevock 2015), wherein Nature's musics inspire creativity and wellbeing.

A little on the history of "nature" (or capitalized "Nature") seems appropriate here. To accomplish this, I draw on Raymond Williams's (1972) seminal essay on nature. He suggested that dictionary definitions are "irrelevant in the case of more complicated ideas" (146). In Williams's review, the term nature is complex and always says something about the society choosing to employ any particular definition. Nature has seemingly conflicting meanings, such as when referring to ourselves (my nature) and everything but ourselves-i.e., that which is not human is labeled nature. The meaning of nature has evolved over time, beginning with the idealist, metaphysical, even "pagan" (148) idea of nature as an essence (e.g., the nature of trees, the nature of fishes, the nature of music); in scholastic, medieval monotheism, this idea became a singular Nature (again, capitalized), usually portrayed either as a female competitor or an agent of God. According to Williams, the personified Nature was revived in the 19th century among Darwinians:

Even men who were prepared to dispense with the first singular principle-to dispense with the idea of God-usually retained and even emphasized that other and very comparable principle: the singular and abstracted, indeed still often and in some new ways personified, Nature. (Williams 1972, 148-9)

This conception of Nature, however, was machine-like-"Nature the selective breeder" (152).

In between scholastic and evolutionary thinkers, and important to education discourses, were Hobbes and Rousseau-Rousseau's thinking provided a precursor to progressive education. They specified competing definitions of nature, with Hobbes coding nature as negative, and Rousseau as positive (Williams 1972, 1546). To Hobbes, life was ruthless, violent, unhappy, and short for people living in a state of nature. For Rousseau, the natural state of life was better than modern living. The natural state was a state of happiness because property makes people

Daniel J. Shevock. 2020. An environmental philosophy for music education based on Satis Coleman's (1878-1961) writings on music and nature. Action, Criticism, and Theory for Music Education 19 (1): 174-207. https://doi.org/10.22176/act19.1.174 
selfish and competitive. Both conceptions of nature represented an a priori state, which led to detaching the concepts "nature" from "human," contributing to an already existing experimental relationship with non-human nature-humans as subjects experiment with nature, including non-human animals as objects. Of these two, Coleman seemed to take a Rousseauean understanding of nature, positively coding the state of being in nature. For Rousseau (1979), a natural education provides space rather than teaches-"What must be done is to prevent anything from being done.... Prior to the calling of his parents is nature's call to human life. Living is the job I want to teach him" (41). As Coleman (1922) echoed, "Few habits are harder to break than that of constraint" (18). Her pedagogy was experimental; children were given space to experiment within nature and with music.

Different definitions of nature are often used simultaneously. Williams (1972) pointed to Shakespeare's King Lear for an example of many conflicting definitions of nature employed in a single short segment of writing:

Allow not nature more than nature's needs,

Man's life's as cheap as beast's ...

... one daughter

Who redeems nature from the general curse

Which twain have brought her to.

That nature, which contemns its origin,

Cannot be border'd certain in itself...

... All shaking thunder...

Crack nature's moulds, all germens spill at once,

That make ungrateful man...

... Hear, nature hear; dear goddess, hear... (151)

Nature here represents a time before human settlements, a fundamental goodness, a less-than-human state of being, the fall and requisite redemption, shapes of nature, reproduction, destructive impersonal force, and the goddess Nature (151).

\section{Nature as pedagogical inspiration}

Coleman used her idea of nature as an inspiration for activities in her approach to teaching music. For her, improvisational elements emerged in natural processes, and nature was an inspiration for musical exploration and learning. As an example,

Daniel J. Shevock. 2020. An environmental philosophy for music education based on Satis Coleman's (1878-1961) writings on music and nature. Action, Criticism, and Theory for Music Education 19 (1): 174-207. https://doi.org/10.22176/act19.1.174 
Coleman (1926) opened her book, First Steps in Playing and Composing, with a story that students were to follow as they experimented with glasses filled with water previously tuned by the teacher:

One day Harry, Jane and William had a party, and ate ice-cream sitting beside a table on the lawn under a big oak tree. The ice-cream was finished. There was left on the table only three glasses of water, and the children drank what they wanted.

Then a funny thing happened. An acorn dropped from the tree to the table and struck one of the glasses. It made a clear, ringing sound. The children looked at one another. Harry tapped the glass with his finger-nail and heard the ringing sound again, much softer. heard.

If you tap glass number 3, you will hear the same kind of sound that Harry

Jane took a small stick from the ground and tapped her glass. It also made a ringing sound, but it was different.

Tap number 1 and see the difference.

"Oh listen!" said William; "tap those two glasses again. They sound like something I have heard in the woods!"

Play 3 then 1, and repeat them several times, and see if you can tell as quickly as Jane did the name of the bird that sings that kind of song.

If you have not heard a real cuckoo, perhaps you have heard the little bird that sings in a "cuckoo" clock. (2-3)

In this example, as nature inspired the approach to learning music (the acorn falling on the empty glass), and then the music reflected back to nature, the students learned something of nature: the cuckoo's birdsong. A contemporary teacher utilizing this approach might provide a type of ecological and ethical experience, especially if the activity leads to a discussion of species or migratory patterns or other ecological challenges. For instance, climate change seems have led to increased Eurasian cuckoo populations in Alaska, threatening native bird species unprepared for the cuckoo's brooding habits (University of Illinois at UrbanaChampaign 2018).

\section{Consumption and conservation}

Long before European explorers began arriving in North America, Turtle Island (a Lanape name for the continent used by many indigenous groups) was home to many ecologically conscious peoples who developed diverse ways of living sustainably within natural limits (Kimmerer 2013). While colonial/settler culture has, in many respects, been environmentally destructive, it has also included

Daniel J. Shevock. 2020. An environmental philosophy for music education based on Satis Coleman's (1878-1961) writings on music and nature. Action, Criticism, and Theory for Music Education 19 (1): 174-207. https://doi.org/10.22176/act19.1.174 
environmental philosophy, critique, and ethics. Likely due to its expansive geography, the "founding gardeners" (Wulf 2012) established the United States of America, which in turn became the birthplace for the nature reserve. Before the 2oth century, the conservation movement emerged-Yellowstone National Park was established in 1872, Sequoia and Yosemite in 1890, and Mount Rainier in 1899. The first half of the 2oth century, which was when Coleman taught, was an important time for conservation in the United States.

The 2oth century began with the great conservationist president, Theodore Roosevelt. Like many in this era, Charles Darwin's evolutionary theory was a strong influence on Roosevelt (Brinkley 2009, 25). Before becoming U.S. president, he was well known for creating wilderness preserves (201) and the Bronx Zoo (276). During his presidency, Roosevelt established 230 million acres as public lands and 250 million acres as national forest. He established national parks at Crater Lake, Wind Cave, and Mesa Verde, in addition to saving Yellowstone through the Park Protection Act.

Conservation continued as a dominant American ethic through the first half of the 2oth century, mostly in response to the observable ecological crises initiated by industrial development. The largest-ever forest fire in America occurred in the states of Idaho, Montana, and Washington in 1910. The links between ecology and economics were strengthened in the emblematic ecological disaster of the 1930s, the Dust Bowl. 9 There was an active conservation movement during Coleman's formative years, and it is possible that the conservation movement affected her music education philosophy. An ecological consciousness, or imagination, has typically been a central part of American thought (Buell 1995), and there is no reason for music education philosophy to be any different. Coleman's writings exemplify ecological ideas in music education.

Most music education philosophy eludes questions of the natural environment, and much has ignored Coleman's contribution. ${ }^{10}$ In recent years, women scholars have led the charge for a more environmentally informed discourse in music education (Jorgensen 1997, Koza 2006, Morton 2012). Morton wrote, "For music educators, teaching to any element of social and ecological problems will, I believe, increasingly generate respect for the merit, the potential, and indeed, the necessity of pursuing these cross-curricular moral imperatives" (488-9).

Daniel J. Shevock. 2020. An environmental philosophy for music education based on Satis Coleman's (1878-1961) writings on music and nature. Action, Criticism, and Theory for Music Education 19 (1): 174-207. https://doi.org/10.22176/act19.1.174 
Presaging this direction, Coleman (1922) saw music education as a part of a broad education:

All that we do for our children is, in some way or other, meant to enrich their lives and prepare them for the experiences which life has in store for them, and most of us feel that musical training comes in for a share of that preparation. (142)

Koza suggested music educators could create goals that are "antithetical to corporate goals" (34), goals that are waste-free and environmentally sustainable.

Coleman employed instrument making in her teaching for several reasons, and it is unlikely that an interest in addressing the waste crisis was among them. Waste, however, has become a critical concern in the 21st century. Musical instrument industries use wood originating in the Global South, negatively affecting the environment (Lafontant Di Niscia 2017, 2019). Contemporary music groups, such as the Landfill Philharmonic, use instrument making to address waste. The Landfill Philharmonic also serves to hold a mirror to the Global North, where most waste is produced (see, for example, Greenwood-Nguyen and Roth 2019). Classical music instruments are not the only tools that result in destroyed ecosystems and create waste. New technologies often have obsolescence built into them: new iPads and computers come out every year and quickly become outdated. Innovation in industrial society is often waste-producing: "Waste compounded many times over by reinforcing in the minds of children the unquestioned goodness and necessity of technological innovation!" (Bates 2013, 81, emphasis in original). Whether for innovative rock and hip-hop ensembles or maintaining school bands and orchestras, the instrument industry is, perhaps, unsustainable (see also Shevock 2019a).

Coleman initially had students make instruments because industry had not yet manufactured non-Western instruments; she later discovered the creative potential instrument-making had for joyful music education.

Many years ago, in the beginning of my experiments with simple instruments there were practically none to be had, so the children and I attempted to make some; and thus from necessity, we were driven headlong into the application of an educational principle, and the discovery of how it worked. Great joy attended their experiments, and as in a vision, a complete picture flashed before me. "The children shall build up their own art, and experience the development of music from the beginning," I said to myself. "I shall find the child's own level, and lift him gradually to higher levels, with the natural evolution of music as my guide in leading the children from the simple to the complex. Primitive man [sic] made his own instruments, and so shall they make theirs." (Coleman 1927a, 18-19)

Daniel J. Shevock. 2020. An environmental philosophy for music education based on Satis Coleman's (1878-1961) writings on music and nature. Action, Criticism, and Theory for Music Education 19 (1): 174-207. https://doi.org/10.22176/act19.1.174 
It may be that singing, repurposing trash-as-classroom-instruments, and simple instrument-making represent better, waste-free, and anti-industrial options. Koza (2006) illuminated:

I am asserting that rather than slavishly supporting consumption and depletion, musicking can foster jouissance and also, in a metaphorical sense, replenish and vivify itself. That this can be done non-consumptively is good news for people and for the environment but perhaps it is not such good news for business, for a corporate world that survives by selling tubas, CDs, textbooks, composition software, and electronic keyboards. (35)

There are certainly links between Coleman's conception of joy and Koza's jouissance. Coleman (1925) emphasized friendship: "Music's greatest value is not to be found in the concert hall, or in any public place where people of great talent play. Its greatest value is found at home and in ensemble playing of friends together" (210). Furthermore, playful singing, dancing, and instrument construction seem the most ecologically sustainable practices available to contemporary music teachers (see also Bates 2013, Matsunobu 2013).

Having students make instruments takes time, however, much of schooling is about efficiency. In this era of neoliberal capitalism, the logic of efficiency as capitalist competition is extended to all areas of social life. ${ }^{11}$ "The object is to establish 'rules of the game' that prevent any deviation from the logic of commodity exchange or capitalist competition, while extending these relations further into society, with the state as the ultimate guarantor of market supremacy" (Foster 2019, 6-7). Efficiency is not only a factual part of schooling in a capitalist society, andperhaps a reason why music education discarded Coleman's popular approach after she retired-efficiency is problematic. Addressing ecological crises requires time for thinking about the past and present and ruminating about possible sustainable futures. Keeping students on-task can leave little time for reflection. None of this can be afforded by teacher-centered efficient teaching approaches, not to mention student-centered approaches embedded in efficiency rationales. Providing time for making instruments, experimenting on them, and even being outdoors listening to non-human musicians in our soundscapes are radical acts that may not be welcome in capitalist schooling today. Job training requires children to learn efficiency, even if it is spiritually, psychologically, and socially destructive.

Daniel J. Shevock. 2020. An environmental philosophy for music education based on Satis Coleman's (1878-1961) writings on music and nature. Action, Criticism, and Theory for Music Education 19 (1): 174-207. https://doi.org/10.22176/act19.1.174 
Undirected time, however, is something music teachers must provide to begin living a little more sustainably, less like unconscious consumers and more like responsible citizens (Shevock 2018, Shevock 2019b). Music educators may be the only teachers left in schools without policymakers staring down their backs with ever-more efficient scripts and high-stakes tests. Music teachers' insider/outsider status in schools (e.g., as "specials") may open space for them to act in inefficient, ecologically sustaining ways.

\section{Epistemology/ethics/policy}

Coleman did not explicitly distinguish between epistemology, ethics, and policy in her writings. Ideas that can be understood as anthropological, and as concerned with the inherent value of non-human musics, emerged in her work. Each of these areas of concern were imbued with epistemological, ethical, and policy aspects.

\section{Anthropological concerns}

Coleman drew heavily on non-Western cultural stories, and her pedagogy has been described as a precursor to world music education (Volk 1996). Coleman's epistemology involved using both Western and non-Western ways of constructing knowledge. As policy, increased use of non-Western instruments and cultural stories may have benefited students by cultivating more intercultural knowledge (Goble 2010).

Coleman (1927b) shared stories and practices of American Indians extensively in her books for the purpose of drawing students' attention to the relationship between culture and environment. For instance:

The Indians of the Southwest make baskets of dried grass and weave beautiful designs in them by using grasses that are dyed in different colors. One of the most important uses of the basket is its use as a drum. The Indians turn it upside down and tap it on the bottom with a drumstick made of yucca palm leaves. There are various basket ceremonies among these Indians. The Navahos have a nine-day basket-dance, and it would require a long time to learn all the various signs and movements to have to be made around the basket, all the motions of the yuccaleaf stick that taps it, and all the figures that are drawn by sprinkling meal on the blanket, or on the buffalo-hide on which the basket rests. (22)

Daniel J. Shevock. 2020. An environmental philosophy for music education based on Satis Coleman's (1878-1961) writings on music and nature. Action, Criticism, and Theory for Music Education 19 (1): 174-207. https://doi.org/10.22176/act19.1.174 
Pedagogically, these stories inspired student instrument construction and improvisation, unlike contemporary world music educators, who use as-authenticas-possible instruments and music in the classroom (Goble 2010, 234-7). Making instruments, however, can also be understood as authentic in many of the world's musical cultures (Matsunobu 2013) (see Image 3).

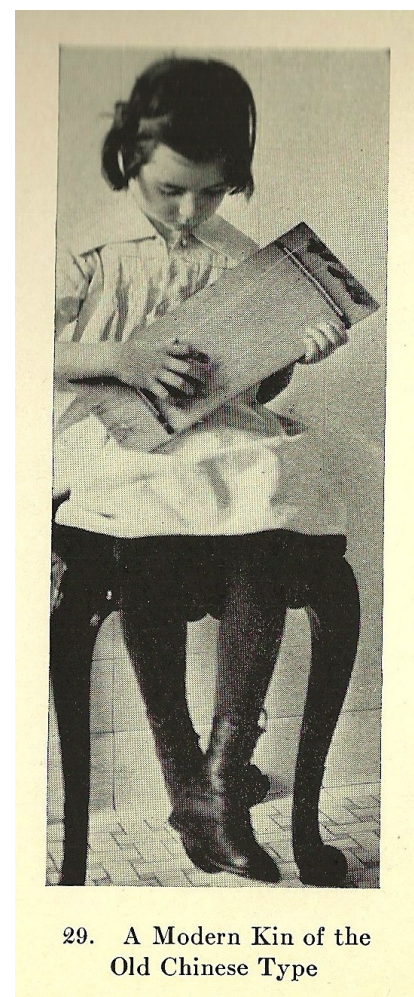

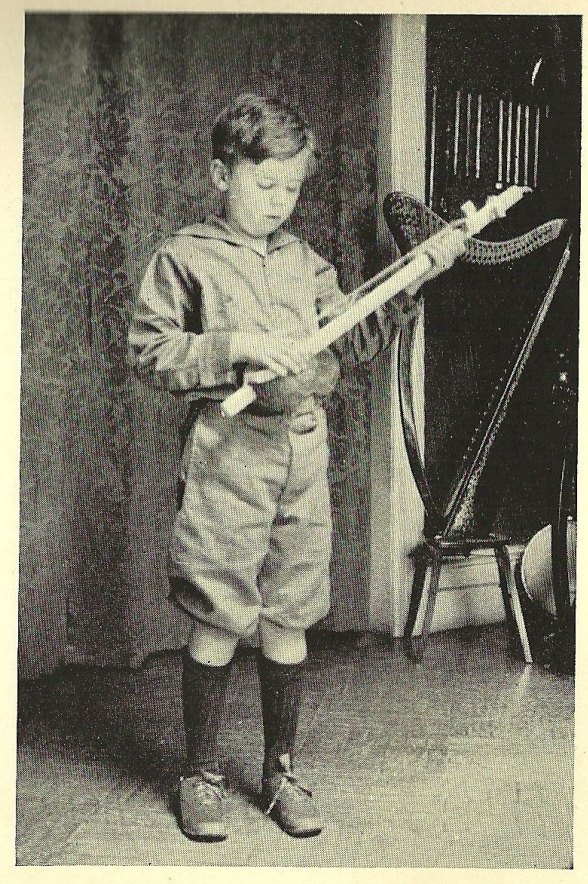

30. Barney Tries His New Cocoanut Banjo

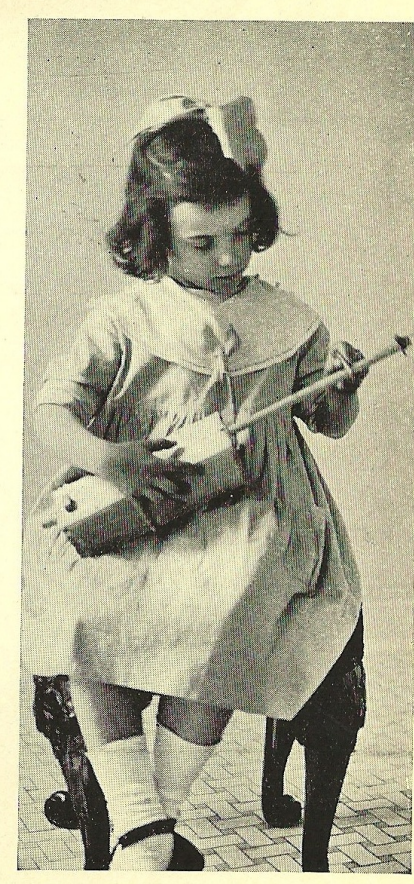

31. The Use of the Movable Bridge is Discovered

Image 3: A Modern Kin of the Old Chinese Type (Coleman 1922, 148 insert)

The ethic of authenticity had not yet been developed in the 1920 s and 30s, but Coleman's inclusion of stories and cultural practices implies that she wanted her students to come to an understanding of non-Western ways of living and thinking.

These ideas, however, did not necessarily cause Coleman to place non-Western cultures on equal footing with Western cultures and musics. "An undertaking was before me: to bring the whole history of music within the reach of the child" (Coleman 1927a, 19). She had an evolutionary understanding of anthropological history which extended to musics: this was a dominant view in the early 2oth century (Fallace 2015, Gustafson 2009, Lesko 1996). For instance, Coleman (1927b) explained to her nephew John, "You will find music stories that show how some of the

Daniel J. Shevock. 2020. An environmental philosophy for music education based on Satis Coleman's (1878-1961) writings on music and nature. Action, Criticism, and Theory for Music Education 19 (1): 174-207. https://doi.org/10.22176/act19.1.174 
musical ideas of the race have grown" (3). Understanding "primitive" musics was part of her philosophy of education, and she envisioned children as evolving through developmental stages, perhaps recapitulating the evolutionary stages of the human race (Southcott 2009). She understood a "natural evolution of music" in which "rhythm came first, then melody, then harmony, then tone-color and shading" as "the process of nature" (Coleman 1917, 50). While problematic, this evolutionary idea was common in child-centered, progressive education in the early 2oth century (Fallace 2015). Carl Orff had similar beliefs and his approach is still popular.

Coleman's anthropological approach resonated with Dewey's (1975) conception of educative culture. "Culture, if it is to be genuinely educative and not an external polish or factitious varnish, represents the vital union of information and discipline. It marks the socialization of the individual in his outlook upon life" (32). Furthermore, Coleman seemed to view other cultures as having worth to the students' creative experiences with music. In her view, non-Western cultural understandings of nature represented an opportunity for increased individual musical and ecological understanding.

\section{Inherent value}

Coleman's pedagogy aimed to understand non-human life. When Coleman (1939) wrote, "And that delightful little time-beater of the evening, the cricket under the leaves" (95), she recognized some value of non-human musics for itself: this ethical stance is called ecocentrism in environmental philosophy (Shevock 2018). The aim of creative improvisation that begins with non-human musics is sense-conscious love: "to love Nature with his ears as well as with his other senses" (95). Coleman also recognized that non-human lifeforms teach and learn: "For several years I had the opportunity to observe the methods of mother robins teaching their little ones to sing, as the trees around my home were nesting places for several families and several generations" (Coleman 1922, 101). That some birds teach their birdsongs to their young is an insight that science has only recognized recently (Doolittle and Gringas 2015).

Coleman's seemingly ecocentric stance aligns with Deep Ecology and the epistemologies of Ecofeminism in environmental philosophy, wherein non-human

Daniel J. Shevock. 2020. An environmental philosophy for music education based on Satis Coleman's (1878-1961) writings on music and nature. Action, Criticism, and Theory for Music Education 19 (1): 174-207. https://doi.org/10.22176/act19.1.174 
lifeforms have inherent/intrinsic value..$^{12}$ As beat poet and deep ecologist Gary Snyder (1995) wrote, of "a wide range of ancient vernacular philosophies ... it is a noninstrumentalist view that extends intrinsic value to the nonhuman natural world" (241). This idea brings Coleman's making and creating (of non-Western instruments) back into the fold of her anthropological view (Snyder's "vernacular philosophies").

\section{Evolution}

Music in embryo.

Primeval forest in Asia. Wind blowing trees to and fro. Running water. Falling rain. Rhythmic lightning. Waves beating rhythmically on the shore.

Deer bounds rhythmically thru the forest. Elephants, swaying bodies and trunks as they walk. Woodpeckers tapping rhythmically. Dancing ostriches. Dancing cranes (Nantucket). Leopard and other animals gracefully running. Monkeys in rhythmic swinging and dancing. (Tree branches still waving rhythmically).

Primitive Man appears, bounding thru the forest. Swims in clear water, with rhythmic strokes. Climbs a tree in graceful rhythm. Chases deer and other animal, and gallops in imitation of it.

Another man appears; they trot and gallop for fun. Several men chase a kangaroo, then they dance the Australian Kangaroo dance in imitation of that animal. A bear appears. Men dance Bear Dance. A large group-dance, giving varied bodily motions and clapping of hands. Expression of different emotions by means of the dance.

(So far, no accompanying sounds except the natural sounds of the forest and animals.) (Coleman n.d.)

The notes above describe an idea Coleman sent to Disney for a series of animated short features, which, though ultimately rejected, may have presaged some of the content included in the film Fantasia.

While I include a critique of evolutionary theory as applied to social thought in the current analysis, it seems important to add a caveat in light of contemporary anti-science politics: ${ }^{13}$ evolutionary theory is the best explanation for understanding biological organisms and systems. No critique herein should be read as skepticism toward the evolution of species; however, beginning in the 19th century, when Darwin's theory was proposed, the extent and ways in which evolution was relevant to social lives had many horrifying missteps, leading to increased racism, classicism, and rationalizations of colonialism-these missteps still affect people today. These include what is generally called Social Darwinism ${ }^{14}$ and the eugenics

Daniel J. Shevock. 2020. An environmental philosophy for music education based on Satis Coleman's (1878-1961) writings on music and nature. Action, Criticism, and Theory for Music Education 19 (1): 174-207. https://doi.org/10.22176/act19.1.174 
movement that culminated in the 1940 s with the Nazi regime's genocide. This type of Social Darwinism persists. ${ }^{15}$ Despite this critique, it may be that evolutionary thinking has helped theorists to better understand some social phenomena, including spirituality and some aspects of music, but not necessarily culture and certainly not White-supremacist understandings of civilization. ${ }^{16}$

Darwin's Origin of Species was "a catalytic event for American thought" (Buell 1995, 6). Dewey (1997) described it as an "intellectual face-about" (3) leading to "the new logical outlook" (9). Not only did evolutionary theory change the direction of the biological sciences, it was vitally important in disciplines such as theology and philosophy, and it led to social movements such as Social Darwinism and eugenics.

It is of little surprise that evolutionary thought influenced American pragmatist philosophers, progressive education and the child-centered movement, including Recapitulation Theory. Recapitulation Theory is a biological and psychological theory that hypothesized that the development of human children paralleled the evolution of animals (with humans at the apex) and races (with "White" at the apex). Progressive education and Recapitulation Theory provided ideas that influenced Coleman and other educational authors who were active in the early 20th century, and many of these same ideas are ubiquitous (although expressed in more politically correct terms) in music education philosophy today.

Dewey, who taught at Columbia University while Coleman attended as a student, understood Darwin's ideas as transformative for philosophical practice. For Dewey (1997), evolutionary theory provided philosophers with new purposes, including social criticism and hypothesis construction, replacing "old" philosophical ideas of the ideal and transcendent (16-19). It may be that Coleman's practicespecific philosophy incorporated much of Dewey's understanding of the Darwinian challenge to philosophy.

Coleman understood music thinking as evolving and strongly linked with social and spiritual life. For instance, when referring to Franz Boas (who also taught at Columbia when Coleman attended and taught), Sir James Frazier and others, she wrote, "Primitive races and simple folk accept without question the life-values of music as a God-given force necessary for the preservation of health, happiness and often even the life of the people" (Coleman 1931, 3). She placed social evolution into stages: "Finally, the strong and naturally vital force of music reached a stage

Daniel J. Shevock. 2020. An environmental philosophy for music education based on Satis Coleman's (1878-1961) writings on music and nature. Action, Criticism, and Theory for Music Education 19 (1): 174-207. https://doi.org/10.22176/act19.1.174 
of extraordinary development in Europe, and brought forth such masters as Bach, Haydn and Beethoven. Great music was written" (7).

Within Recapitulation Theory, children reenacted the stages of evolution in schools-from so-called primitive to more evolved cultures. Coleman's understanding of music history as evolving through stages seemed to reinforce the idea of recapitulation. "Everything that a primitive savage can do in music, children can do" (Coleman 1922, 30). But I feel reticent to describe Coleman's approach as Recapitulation Theory, because Coleman didn't see it as recapitulation (Coleman 1922, 143 footnote), and room should be left for her philosophy to have changed during her career. Whether or not she understood her work as recapitulation, she understood the basic assumptions underlying recapitulation as a component of child-centered teaching. "All modern educators are agreed on the fundamental principles enunciated by Pestalozzi, that the arrangement of matter and method must correspond with the order of the evolution of that branch of knowledge" (Coleman 1917, 50).

This evolutionary understanding provided an opening for her critique of modern musical culture. She wrote, "Genius raced ahead, and the people were left behind" (Coleman 1931, 7), and elsewhere, "In the case of these children, civilization has not deprived them of their birthright of feeling animal freedom" (Coleman 1922, 82). She also took a critical social position:

And the masses? There is a halo around the head of the artist who brings the greatest box office receipts, and the people buy their vicarious enjoyment of music as the fashion of the time dictates and learn to "appreciate" as best they can (Coleman 1931, 9).

This critique of the well-worn term appreciation fits well within the Praxial Turn, with participation and musical doing again gaining prominence above aesthetic appreciation (Goble 2010, 203-6 and 237-45); however, each of these quotes has a negative side.

In 1915, President Woodrow Wilson screened The Birth of a Nation in the White House. In 1921, White citizens in Tulsa destroyed the Greenwood District, then known as Black Wall Street, killing between 100 and 300 African Americans. In 1925, between 25,000 and 50,000 Ku Klux Klan members marched on Washington demanding immigration restrictions. The zeitgeist of which Coleman was a part is similar to the zeitgeist today. ${ }^{17}$ Child-centered pedagogy was, and is now, a

Daniel J. Shevock. 2020. An environmental philosophy for music education based on Satis Coleman's (1878-1961) writings on music and nature. Action, Criticism, and Theory for Music Education 19 (1): 174-207. https://doi.org/10.22176/act19.1.174 
leading idea in education. Fallace (2015) observed, "Educators have largely forgotten that child-centered pedagogy emerged from the pervasive ethnocentric/racist belief in the equivalence of White children and non-White adults" (98). Coleman (1917) drew from the father of Social Darwinism, Herbert Spencer, in her earliest publication..$^{18}$ In music education in the 1920s, non-White music "played the role of 'primitive' music for the young grades, intended as the path to developing the sophisticated (White) listener schooled in the Eurocentric canon" (Hess 2017, 20; see also Gustafson 2009). Coleman's philosophy seemed to represent this thinking, but her approach was not as listener-centric as other music education philosophers at the time, especially those focused on music appreciation.

During the period when Coleman was active, notions of stages of musical evolution were connected with emerging stages of human development, which introduces ambiguity to the equation. As Gustafson (2009) wrote, "Development that was formerly frozen for more primitive types became the more flexible progress one might expect from the individual in a democracy" (104, emphasis in original). This was the progressive, democratic music education of the first half of the 2oth century within which Coleman-along with contemporaries like Will Earhart and James Mursell-was a well-known figure. Even if not a part of the horrible eugenics movement, evolutionary theory and democratic education were suspiciously close to those ideas.

Lesko (1996) suggested that Recapitulation Theory contained an androcentric component also, "a form of biological determinism, the belief that people at the bottom of the social hierarchy are there because they are naturally inferior (because of poor brains, bad genes, female gender, or whatever)" (462). Certainly, these ideas were readily apparent in the work of Recapitulation Theory's bestknown proponent, G. Stanley Hall (see Hall 1900, 92), who wrote the introduction to Coleman's (1922) Creative Music for Children. Coleman's understanding of evolution reinforced aspects of this understanding of gender, while challenging others. To exemplify the complexity of Coleman's thought, in discussing the paucity of women composers, Coleman (1917) wrote this:

Women are naturally more timid and conservative than men, and not so prone to adventure. A man, like a wild horse, naturally breaks out of harness and explores other pastures. A woman's brain and nerve tissue are as capable of musical development as a man's; but our backhanded training has not fostered the art sufficiently for it to blossom universally, and most of our genius has been crushed

Daniel J. Shevock. 2020. An environmental philosophy for music education based on Satis Coleman's (1878-1961) writings on music and nature. Action, Criticism, and Theory for Music Education 19 (1): 174-207. https://doi.org/10.22176/act19.1.174 
except in the bold and unruly sex. If music were developed in a natural way, another century would probably give us plenty of genius of both sexes. Heretofore, our composers, especially in America, have developed in spite of their training, and not because of it. (62, emphasis in original)

Here, Coleman's first statement represents Lesko's (1996) idea of biological determinism by suggesting women are "naturally more timid," but in contrast with Lesko, Coleman (1917) posited that a "natural way" of teaching and learning music was a critical issue, because women's "brain and nerve tissue are as capable" (62). Coleman's understanding was that a natural method would enable women to accomplish achievements equal to that of men. This seems more in line with Dewey's (1997) understanding that evolution provided a model for "a method of moral and political diagnosis and prognosis" (17). Coleman was diagnosing the problem of gender inequality and forecasting the likely course through which equality could be attained.

\section{A Placing}

When the chesty, fierce-furred bear becomes sick he travels the mountainsides and the fields, searching for certain grasses, flowers, leaves and herbs that hold within themselves the power of healing. He eats, he grows stronger. Could you, oh clever one, do this? Do you know anything about where you live, what it offers? Have you ever said, "Sir Bear, teach me. I am a customer of death coming, and would give you a pot of honey and my house on the western hills to know what you know." (Oliver 2016, 6)

It seems the self, the ecological self, emerges fundamentally within specific places. Gary Snyder (1995) wrote:

How does knowledge of place help us know the Self? The answer, simply put, is that we are all composite beings, not only physically but intellectually, whose sole individual identifying feature is a particular form or structure changing constantly in time. There is no "self" to be found in that, and yet oddly enough, there is. Part of you is out there waiting to come into you, and another part of you is behind you, and the "just this" of the ever-present moment holds all the transitory little selves in its mirror. The Avatamsaka ("Flower Wreath") jeweled-net-interpretation-ecological-systems-emptiness-consciousness tells us no self-realization without the Whole Self, and the whole self is the whole thing. Thus, knowing who we are and knowing where we are intimately linked. (189)

Perhaps Turtle Island might cultivate in those living there a compulsion to posit an environmental philosophy. It may be that this place, this soil, demands it, even

Daniel J. Shevock. 2020. An environmental philosophy for music education based on Satis Coleman's (1878-1961) writings on music and nature. Action, Criticism, and Theory for Music Education 19 (1): 174-207. https://doi.org/10.22176/act19.1.174 
if institutions and society do not. I wonder why so many music education philosophies ignore environment, except in the narrowest pedagogical sense. I suspect this ignoring is due to the Eurocentric philosophical tradition (see Shevock 2017, 55), which has a long history of placing emphasis on the mind above the body, wealth above poverty, human action above non-human action, Whites above nonWhites, and men above women (see also Hess 2017); however, I believe revisiting the ideas of historical women thinkers may help music educators do better.

That Coleman's writings incorporated an environmental philosophy stands at odds with much of music education's past and present. Coleman's writings could have been overlooked due to her use of colonialist language, but colonialist tendencies remain, even while music education scholars discarded Coleman's environmental ideas. In this essay, I have argued, perhaps strongly at times, that Coleman's philosophy contained racist and colonialist elements; however, her philosophy should not be understood as androcentric, though her conceptions of gender equality may be different than those many people hold today. Coleman used Boas's writings in her 1931 dissertation, and Boas (along with Ruth Benedict) was well known for moving anthropological scholarship toward cultural relativism. Coleman's use of Boas's work may have represented a shift in her thinking, from recapitulation to Boas's anti-racist relativism, but not necessarily or automatically so. I do not want to present Coleman as a hero (a Great Man, such as in 19th century Great Man history). ${ }^{19}$ Coleman was a complicated, thorny, and sophisticated thinker. She was a product of her time, but also offers many ideas music educators can use today. As early as in her 1922 book, Coleman did not view her work as supporting "the once popular Recapitulation Theory" (Coleman 1922, 143 footnote; this is from the same book for which G. Stanley Hall ${ }^{20}$ wrote the introduction), but many of her ideas were suspiciously close to racist Recapitulation Theory and can be read unequivocally as such (Southcott 2009).

That there were problematic elements should not be surprising: Music educators understand the other in imperfect ways even today (Shevock 2015). In particular, many White, middle-class music education scholars may steer away from indigenous authors, especially American Indian philosophy, to avoid the possibility of oversimplifying or misusing non-White scholarship. Coleman likely misused Native American ideas. Avoiding this work, however, does not lessen racist, colonial, anthropocentric, or androcentric thinking. It merely renews generations of

Daniel J. Shevock. 2020. An environmental philosophy for music education based on Satis Coleman's (1878-1961) writings on music and nature. Action, Criticism, and Theory for Music Education 19 (1): 174-207. https://doi.org/10.22176/act19.1.174 
racist, sexist, classist, ecologically illiterate yahoos who never interrogate deeply held unjust hierarchies, and it silences groups of people just because their ideas are difficult to negotiate in music discourse.

We who are writing about the other have imperfect understandings of the other. Just as Coleman's words, at times, seem brutal to readers in the 21st century, I suspect our yearnings for better ways to understand each other will seem brutal in the 22nd. Scholars work within unjust institutions that emerged from personal and social histories of injustice, and are taught to critique those institutions even while learning from them. That makes attempts-our own missteps-essential work. Scholarly silence may represent a great opponent to equity.

When it comes to considering ecological crises, steering clear of indigenous philosophies-which contain many of the best possible ideas for living well in place-is not a viable option..$^{21}$ In the Global North, people become so consumption-driven that they are destroying themselves psychologically, spiritually, and physically. If the stories and myths of White cultures fail to provide a language to address self-destructive actions, studying other stories and myths may help.

The Windigo (mythical cannibal monsters or evil spirits) emerged from Cree mythology and have found their way into mythology other than Cree. Potawatomi scientist Robin Wall Kimmerer (2013) wrote:

Each of us comes from people who were once indigenous. We can reclaim our membership in the cultures of gratitude that formed our old relationships with the living earth. Gratitude is a powerful antidote to Windigo psychosis. Deep awareness of the gifts of the earth and of each other is medicine.... Gratitude for all the earth has given us lends us courage to turn and face the Windigo that stalks us, to refuse to participate in an economy that destroys the beloved earth to line the pockets of the greedy, to demand an economy that is aligned with life, not stacked against it. (337)

I hear resonance between Kimmerer's gratitude and Coleman's love (Coleman 1939). Undoubtedly, Coleman's understanding of Native Americans was imperfect, even if it was progressive for the 1920 s and 30s. After centuries of colonial thinking, decolonizing the people of the Global North's minds and communities will require decades, if not centuries, of work. I understand Coleman's scholarship as one part of that work in music education. The work likely will involve many misstepsbut these are missteps we must take if we are to recognize our responsibility for sustaining and rejuvenating Mother Earth.

Daniel J. Shevock. 2020. An environmental philosophy for music education based on Satis Coleman's (1878-1961) writings on music and nature. Action, Criticism, and Theory for Music Education 19 (1): 174-207. https://doi.org/10.22176/act19.1.174 
Buell (1995) discussed Thoreau and Darwin as essential figures in modifying how we understand history: "We now imagine nineteenth century thought as leading up to Darwin and early American environmental writing as an antediluvian phase "before Thoreau" (442). Though I have found little evidence indicating that Coleman considered the thinking of Thoreau (who utilized his imperfect understanding of Hindu mythology), her work certainly drew heavily from Darwin, pulling evolutionary theory into music education philosophy. Coleman created a music education philosophy that opened up space for important conversations about nature: these are conversations we need to have today.

Today, we may be able to revisit some of Coleman's practices and avoid some of the pitfalls of evolutionary thinking in the early 2oth century. The Social Darwinist and Recapitulationists' pyramid, with Western civilization on top, may need to be turned over, as many indigenous societies have been living sustainably for more than 200,000 years, while industrial culture has brought us to the brink of destruction in a short 200 years. Music teachers informed by eco-literate pedagogy can incorporate key ideas modified from Coleman's philosophy:

1. Mother Earth personifies a spiritual force, from whom musics emerge

2. Non-human musics provide pedagogical inspiration, especially when music educators take their students outdoors

3. Using repurposed and recycled instruments can help music teachers to simultaneously incorporate creative activities and reduce waste

4. Efficiency can work against creative music education and sustainability

5. Music education can help students make meaningful connection to the other by using non-Western musics and stories

6. Non-human beings have inherent value, and performing and teaching music is not unique to human beings

7. Considering evolutionary theory can help us understand environmental and social matters, but we need to avoid the racist missteps of Social Darwinism and Recapitulation Theory

An important question we might ask is how we might recover sustainable, intergenerational, long-placed cultures from which we have unwittingly dismembered ourselves. Much ecomusicological scholarship draws heavily on conceptions of place, and critiques of nature/culture binaries (Allen and Dawe 2016, 5).

Daniel J. Shevock. 2020. An environmental philosophy for music education based on Satis Coleman's (1878-1961) writings on music and nature. Action, Criticism, and Theory for Music Education 19 (1): 174-207. https://doi.org/10.22176/act19.1.174 
Ecomusicological research can draw our attention to cultures other than our own, which often have different conceptions of society and nature; these can inform how we choose to live today. Whatever we do, music educators must address the ecological crises, and it may be that the best way to chart a course forward is by looking back from where we currently stand, which I have attempted to do with this study of Satis Coleman's music education philosophy as environmental philosophy.

\section{About the Author}

Music education philosopher Daniel J. Shevock is the author of Eco-Literate Music Pedagogy (Routledge), peer-reviewed articles, and the Eco-Literate Pedagogy blog at eco-literate.com. He teaches at Penn State Altoona (USA). He earned a Ph.D. in Music Education at Penn State, a master's degree at Towson University, and a bachelor's degree at Clarion University of Pennsylvania. Dan's scholarship blends creativity, ecology, and critique.

\section{References}

Allen, Aaron S. and Kevin Dawe. 2016. Ecomusicologies. In Current directions in ecomusicology: Music, culture, nature, edited by Aaron S. Allen and Kevin Dawe, 1-15. New York: Routledge.

Bates, Vincent C. 2013. Music education unplugged. Action, Criticism, and Theory for Music Education 12 (2): 75-90.

Bates, Vincent C. 2016. Toward a sociology of music curriculum integration. Action, Criticism, and Theory for Music Education 15 (3): 8-20.

Boston, Sheila C. 1992. Satis N. Coleman (1878-1961): Her career in music education. Doctoral diss., Univerity of Maryland.

Brinkley, Douglas. 2009. The wilderness warrior: Theodore Roosevelt and the crusade for America. New York: Harper Perennial.

Buell, Lawrence. 1995. The environmental imagination: Thoreau, nature writing, and the formation of American culture. Cambridge: Harvard University Press.

Coleman, Satis N. 1917. Children and music: A heretic's views on the present system of teaching. The Musical Observer (September): 50+60-62.

Coleman, Satis N. 1922. Creative music for children. New York: G. P. Putnam's Sons.

Daniel J. Shevock. 2020. An environmental philosophy for music education based on Satis Coleman's (1878-1961) writings on music and nature. Action, Criticism, and Theory for Music Education 19 (1): 174-207. https://doi.org/10.22176/act19.1.174 
Coleman, Satis N. 1925. Creative music for children. Proceedings of the Music Teachers National Association 205-217. NAfME Archives Collection 0164SCPA Satis Coleman Collection. College Park, MD.

Coleman, Satis N. 1926. First steps in playing and composing: A music book for children. New York: John Day.

Coleman, Satis N. 1927a. Creative experience through making musical instruments. Progressive Education: A Quarterly Review of the Newer Tendencies in Education 4 (1): 18-23.

Coleman, Satis N. 1927b. Master book III: Creative music in the home. Valparaiso: Lewis E. Meyers.

Coleman, Satis N. 1931. A children's symphony: As developed in the creative music classes of Lincoln School of Teachers College. New York: Bureau of Publications of Teachers College. PhD diss., Columbia University.

Coleman, Satis N. 1938. The book of bells. New York: John Day.

Coleman, Satis N. 1939. Your child's music. New York: Van Rees Press.

Coleman, Satis N. 1942. Songs of American folks. New York: John Day.

Coleman, Satis N. n.d. A sound-film showing the evolution of the art of music (skeletal outline). File folder: "Notes on the evolution of music" signed by Satis N. Coleman. NAfME Archives Collection 0164-SCPA Satis Coleman Collection. College Park, MD.

Dewey, John. 1975. Moral principles in education. Carbondale: Southern Illinois University Press. [Originally published 1909]

Dewey, John. 1997. The influence of Darwin on philosophy and other essays. Amherst: Prometheus Books. [Originally published 1910]

Doolittle, Emily, and Bruno Grinas. 2015. Quick guide: Zoomusicology. Current Biology 25 (October): R811-R826.

Elliott, David J. and Marissa Silverman. 2015. Music matters: A philosophy of music education, 2nd ed. New York: Oxford University Press.

Fallace, Thomas. 2015. The savage origins of child-centered pedagogy, 1871-1913. American Educational Research Journal 52 (1): 73-103.

Daniel J. Shevock. 2020. An environmental philosophy for music education based on Satis Coleman's (1878-1961) writings on music and nature. Action, Criticism, and Theory for Music Education 19 (1): 174-207. https://doi.org/10.22176/act19.1.174 
Fitch, W. Tecumseh. 2005. The biology and evolution of music: A comparative perspective. Cognition 100 (1): 173-215. http://doi.org/10.1016/j.cognition.2005.11.009

Foster, John Bellamy. 2019. Absolute capitalism. Monthly Review 71 (1): 1-13.

Giroux, Henry A. 2019. Authoritarianism and the challenge of higher education in the age of Trump. Action, Criticism, and Theory for Music Education 18 (1): 6-25. http://doi.org/10.22176/act18.1.6

Goble, J. Scott. 2010. What's so important about music education? New York: Routledge.

Greenwood-Nguyen, Alisa, and Robin J. Roth. 2019. Plastic in the oceans is not the fault of the global south. Science $X$ (February 1). https://phys.org/news/2019-02-plastic-oceans-fault-global-south.html.

Gustafson, Ruth Iana. 2009. Race and curriculum: Music in childhood education. New York: Palgrave MacMillan.

Hall, G. Stanley. 1900. Student customs. Proceedings of the American Antiquarian Society 14 (October): 83-124.

Hess, Juliet. 2017. Equity and music education: Euphemisms, terminal naivety, and Whiteness. Action, Criticism, and Theory for Music Education 16 (3): 1547.

Jorgensen, Estelle. 1997. In search of music education. Urbana: University of Illinois Press.

Kimmerer, Robin Wall. 2013. Braiding sweetgrass: Indigenous wisdom, scientific knowledge, and the teachings of plants. Minneapolis: Milkweed Editions.

Koza, Julia Eklund. 2006. "Save the music"?: Toward culturally relevant, joyful, and sustainable school music. Philosophy of Music Education Review 14 (1): $23-38$.

Kropotkin, Peter. 1902. Mutual aid: A factor in evolution. New York: McClure, Philips \& Company. Edition published by Jonathan-David Jackson.

Lafontant Di Niscia, Attilio. 2017. Sobre el proceso de adquisición de instrumentos musicales de El Sistema: Hacia una epistemología ecológica en la educación musical. Revista Internacional de Educación Musical 5: 157-64.

Daniel J. Shevock. 2020. An environmental philosophy for music education based on Satis Coleman's (1878-1961) writings on music and nature. Action, Criticism, and Theory for Music Education 19 (1): 174-207. https://doi.org/10.22176/act19.1.174 
Lafontant Di Niscia, Attilio. 2019. Unveiling the dark side of tonewoods: A case study about musical instrument demand for the Venezuelan youth orchestra El Sistema. Action, Criticism, and Theory for Music Education 18 (3): 25988. http://doi.org/10.22176/act18.3.259

Lesko, Nancy. 1996. Past, present, and future conceptions of adolescence. Educational Theory 46 (4): 453-72.

Matsunobu, Koji. 2013. Instrument-making as music-making: An ethnographic study of shakuhachi students' learning experiences. International Journal of Music Education 31 (2): 190-201.

Morton, Charlene A. 2012. Music education for "all my relations." In The Oxford handbook of philosophy in music education, edited by Wayne D. Bowman and Ana Lucía Frega, 472-91. Oxford: Oxford University Press.

NAfME News. 2010. Two pioneering music educators to be inducted into music educators hall of fame. https://nafme.org/two-pioneering-music-educatorsto-be-inducted-into-music-educators-hall-of-fame/

Oliver, Mary. 2016. Upstream. New York: Penguin Press.

Reimer, Bennett. 1989. A philosophy of music education, 2nd ed. Englewood Cliffs: Prentice Hall.

Rothenberg, David. 2008. Whale music: Anatomy of an interspecies duet. Leonardo Music Journal 18: 47-53.

Rousseau, Jean-Jacques. 1979. Emile or on education: Introduction, translation, and notes by Allan Bloom. New York: Basic Books. [Originally published 1762]

Sarkar, Sahotra. 2012. Environmental philosophy: From theory to practice. Chichester: Wiley-Blackwell.

Scarfe, Adam C. 2010. On religious violence and Social Darwinism in the new atheism: Toward a critical panselectionalism. American Journal of Theology \& Philosophy 31 (1): 53-70.

Shevock, Daniel J. 2015. Satis Coleman-A spiritual philosophy for music education. Music Educators Journal 102 (1): 56-61. http://doi.org/10.1177/ 0027432115590182

Shevock, Daniel J. 2017. Thoughts on the law, gatekeepers, and rerooting. Action, Criticism, and Theory for Music Education 16 (1): 53-65.

Daniel J. Shevock. 2020. An environmental philosophy for music education based on Satis Coleman's (1878-1961) writings on music and nature. Action, Criticism, and Theory for Music Education 19 (1): 174-207. https://doi.org/10.22176/act19.1.174 
Shevock, Daniel J. 2018. Eco-literate music pedagogy. New York: Routledge.

Shevock, Daniel J. 2019a. Waste in popular music education: Rock's problematic metaphor and instrument-making for eco-literacy. TOPICS for Music Education praxis 2019 (2): 37-56.

Shevock, Daniel J. 2019b. Peace, place, and then...: A practice of silence. PMEA News: The Official Publication of the Pennsylvania Music Educators Association 83 (3): 14-15.

Shevock, Daniel J., and Vincent C. Bates. 2019. A music educator's guide to saving the planet. Music Educators Journal 105 (4): 15-20. http://doi.org/10.1177/ 0027432119843318

Shiva, Vandana. 1992. Women's indigenous knowledge and biodiversity conservation. India International Centre Quarterly 19 (1/2): 205-214.

Snyder, Gary. 1995. A place in space: Ethics, aesthetics, and watersheds. Berkeley: Counterpoint.

Southcott, Jane. 1990. A music education pioneer-Dr. Satis Naronna Barton Coleman. British Journal of Music Education 7 (2): 123-32.

Southcott, Jane. 2009. The seeking attitude: Ideas that influenced Satis N. Coleman. Journal of Historical Research in Music Education 31 (1): 20-36.

Tellstrom, A. Theodore. 1971. Music in American education: Past and present. New York: Hold, Rinehart and Winston.

University of Illinois at Urbana-Champaign. 2018. Russian cuckoo invasion spells trouble for Alaskan Birds. Science Daily (May 7). https://www.sciencedaily.com/releases/2018/05/180507111826.htm

Volk, Terese M. 1996. Satis Coleman's "creative music": Hands-on music education for children was the goal of the innovative music educator Satis Coleman. $M u-$ sic Educators Journal 82 (6): 31-33+47. http://doi.org/10.2307/3398949

Whatmore, Richard. 2016. What is intellectual history? Cambridge: Polity Press. [Kindle version]

Williams, Raymond. 1972. Ideas of nature. In Ecology, the shaping enquiry, edited by J. Benthall, 146-64. London: Longman Group Limited.

Wulf, Andrea. 2012. Founding gardeners: The revolutionary generation, nature, and the shaping of the American nation. New York: Vintage.

Daniel J. Shevock. 2020. An environmental philosophy for music education based on Satis Coleman's (1878-1961) writings on music and nature. Action, Criticism, and Theory for Music Education 19 (1): 174-207. https://doi.org/10.22176/act19.1.174 


\section{Notes}

${ }^{1} \mathrm{http}$ ///www.unesco.org/education/tlsf/mods/theme_a/img/o2_earthcharter.pdf

${ }^{2}$ http://www.maydaygroup.org/about-us/action-for-change-in-music-education/

3 See Goble (2010), who traced the idea of Music Education as Aesthetic Education to Bennett Reimer's dissertation, though music educators had viewed their practice "as a way of 'cultivating the feelings' ... since Lowell Mason first introduced music into the Boston schools in 1837" (228). For the purposes of this paper, I call the era between Reimer's dissertation and the praxial critiques of it-especially by David Elliott, Thomas Regelski and others-the era of Music Education as Aesthetic Education, However, as with any suggested historical period, its values stretch before and after the years in question (approximately, 1963-1995), with 1995 as the year Elliott published the first edition of Music Matters (238). Similarly, the Tanglewood symposium of 1967 (which Goble pointed out was just three years after Reimer's dissertation) can be seen as a culmination of a progressive era for music education. Coleman published her first publication in 1917, though progressive ideas may have been published prior to this date-Will Earhart's Music in the Secondary Schools was published in 1918, Music Supervisors Journal was first published in 1914. For the purposes of this paper then, I see music education history as proceeding from The Progressive Era (approximately 1917 to 1963), to $\mathrm{Mu}-$ sic Education as Aesthetic Education (1963-1995), to the Praxial Turn (1995-date), with ideas from each era emerging before the dates given and continuing today.

4 Through email, Jane Southcott, whose research influenced my own studies of Coleman, shared a statement she procured from Teachers College Columbia University's Office of the Registrar dated July 19, 1983, providing the following dates for Coleman's degree conferrals: B.S. 6/1/1927, M.A. 6/6/1928, and Ph.D. 10/19/1937 (personal correspondence January 4, 2018). Coleman also had earned a teaching certificate from the State Normal School in Huntsville, Texas in 1895 (Boston 1992, 15). Also, in her first "Special Courses in Music Education," in 1925 Coleman taught two courses at Teachers College: "Musical Material for Festivals and Special Occasions," and "Creative Music in the Elementary School" (88). Coleman's courses at Teachers College, which coincided with Peter Dykema's time as head of the music department, were "never very large" (90).

5 See also Bates 2016.

Daniel J. Shevock. 2020. An environmental philosophy for music education based on Satis Coleman's (1878-1961) writings on music and nature. Action, Criticism, and Theory for Music Education 19 (1): 174-207. https://doi.org/10.22176/act19.1.174 
${ }^{6}$ For Elliott and Silverman (2015), philosophy is something done: "doing philosophy contributes to a deeper sense of personal and professional meaning and opens our eyes to wider possibilities of human experience, including our experiences as musicians, teachers, and ethical human beings" (27). Though I am not attempting to attain Elliott and Silverman's criteria for philosophy of music education, Coleman considered her work philosophy of music education, and I think she did hope to "contribute to a deeper sense of personal and professional meaning" and "open[] our eyes to wider possibilities of human experience."

7 It is a well-worn idea in the history of philosophy that Plato and Aristotle represented the two principal strands of philosophical discourse, which continues through Augustine (Platonic) and Aquinas (peripatetic), through today. At present, continental philosophers write more artistically and analytic philosophers more systematically, but when looking at a thinker in depth, there are times when the distinction between artistic and systematic breaks down.

${ }^{8}$ Since she referenced both Plato and Aristotle in her dissertation, it seems probable that in using the word "happiness" she referred to Platonic and Peripatetic conceptions of eudaimonia, a term often translated into English as "happiness" or "flourishing."

9 The poor, women, and people of color suffered the most from this ecological crisis. See the entry in Encyclopedia of the Great Depression, on "Impact of the Great Depression on Women," https://www.encyclopedia.com/economics/encyclopedias-almanacs-transcripts-and-maps/women-impact-great-depression, and the Library of Congress's "Songs of the Great Depression and the Dust Bowl Migrants," https://www.loc.gov/item/ihas.200197402/

${ }^{10}$ It is possible that other voices discussed nature and music education prior to the era of Music Education as Aesthetic Education, including other female music educators. Uncovering those voices, however, is beyond the scope of the current paper.

${ }^{11}$ See Giroux (2019). He wrote, "These anti-democratic tendencies are evident in the ways in which neoliberalism since the 1980 os has reshaped formal education at all levels into a site for training, inundating market values, and imposing commercial relations as a template for governing all of social life" (8).

${ }^{12}$ See Shiva's Ecofeminism for a discussion of the intrinsic value of nature's diversity. Shiva (1992) for instance wrote of Navdanya: "Women have been the selectors and custodians of seed. When they conserve seed, they conserve diversity and when they conserve diversity, they conserve a balance and harmony. 'Navdanya' or nine seeds are the symbol of this renewal of diversity and balance, not just of the

Daniel J. Shevock. 2020. An environmental philosophy for music education based on Satis Coleman's (1878-1961) writings on music and nature. Action, Criticism, and Theory for Music Education 19 (1): 174-207. https://doi.org/10.22176/act19.1.174 
plant world, but of the planet and social world. It is this complex, relational web which gives meaning to biodiversity in Indian culture and has been the basis of its conservation over millennia. / Sacredness is a large part of conservation in the indigenous setting and carries with it the intrinsic value of diversity" (211).

${ }^{13}$ Giroux (2019) suggested that a large percentage of the U.S. think creationism ought to be taught in public schools. "As ignorance becomes one of the primary organizing principles of American society, all traces of critical thought migrate to the margins of the culture" (11).

${ }^{14}$ It should also be noted that Social Darwinism was dominant, but not universally accepted in the early 20th century. The Russian anarchist and geographer Peter Kropotkin (1902) wrote a criticism of Social Darwinism. Social Darwinism emphasized a narrow conception of survival of the fittest but ignored mutual aid in Darwin's writings. Though both competition and mutual aid can be found in Darwin's writings, Herbert Spencer emphasized competition to validate capitalist consumption and inequality, while Kropotkin's observations of animal cooperation in Eastern Siberia and Northern Manchuria led him to conclude, "The mutual protection which is obtained in this case, the possibility of attaining old age and of accumulating experience, the higher intellectual development, and the further growth of sociable habits, secure the maintenance of the species, its extension, and its further progressive evolution. The unsociable species, on the contrary, are doomed to decay" (158).

15 Giroux (2019) discussed how with the Trump presidency, "In some cases, altright and neo-Nazi groups are issuing death threats against faculty who speak out against racism and other volatile social issues" (12-13). Also, New Atheism seems linked to Social Darwinism. According to Scarfe (2010), biotic violence is often treated as natural, which Social Darwinists extend to naturalizing violence between humans for supposed evolutionary gain. He continued, "The New Atheists are either unconscious of these matters or are simply silent about the implicit Social Darwinism that lingers in them" (59-60). At least one New Atheist has not been silent. See endnote 19.

${ }^{16}$ Because of the complexity of evolutionary theory as it relates to music education, a deeper look at Coleman's use of evolutionary thinking in music education is important, and it deserves more extended treatment than I will give it here. The focus of this essay is evolutionary theory as one part of Coleman's overall music education philosophy, which I analyze as environmental philosophy.

Daniel J. Shevock. 2020. An environmental philosophy for music education based on Satis Coleman's (1878-1961) writings on music and nature. Action, Criticism, and Theory for Music Education 19 (1): 174-207. https://doi.org/10.22176/act19.1.174 
17 Religion critic Sam Harris recently and infamously exhumed Social Darwinist ideas linking intelligence and race. His argument has a following on YouTube. See link: https://youtu.be/RBINzxe4g2c

18 "Herbert Spencer said that when a teacher of any language begins that study with drilling in the parts of speech and their functions, his course is as unreasonable as to preface the art of walking by a course of lessons on the bones, muscles and nerves of the legs" (Coleman 1917, 50).

19 See https://en.wikipedia.org/wiki/Great_man_theory

${ }^{20}$ To complicate the history of Recapitulation Theory, even though Hall's ideas were explicitly racist, perhaps his most famous student was Francis Sumner, the first African American to earn a Ph.D. in psychology (at Lincoln University in 1920). According to the African American Registry, "In many ways, comments that G. Stanley Hall had made seemed to be prejudiced and degrading to African Americans, but Hall's actions towards African Americans supported not only Sumner but also the advancement of many African Americans at Clark and in the field of psychology.” See https://aaregistry.org/story/francis-c-sumner-born/

${ }^{21}$ In his discussion of sumac kawsay as an epistemological possibility for music education, Lafontant (2019) writes, "One of the first steps for reverting this predatory process should be the collective understanding of an ecological epistemology-previously embedded in discourses of indigenous and social movements-to confront developmentalism infused into neoliberalism, which in historical memories of some Latin American native communities is encapsulated in the concept sumac kawsay" (277, emphasis in original). The use of indigenous concepts to direct our attention to ecological crises is often lacking in music education scholarship.

Daniel J. Shevock. 2020. An environmental philosophy for music education based on Satis Coleman's (1878-1961) writings on music and nature. Action, Criticism, and Theory for Music Education 19 (1): 174-207. https://doi.org/10.22176/act19.1.174 